\title{
BMJ Open Synergistic effect of hypoalbuminaemia and hypotension in predicting in- hospital mortality and intensive care admission: a retrospective cohort study
}

\author{
Eyal Klang, ${ }^{1,2}$ Shelly Soffer (D) ,3,4 Eyal Zimlichman, ${ }^{2,5}$ Alexis Zebrowski, ${ }^{6,7}$ \\ Benjamin S Glicksberg, ${ }^{8,8}$ E Grossman, ${ }^{2,9}$ David L Reich, ${ }^{10}$ Robert Freeman, ${ }^{11}$ \\ Matthew A Levin ${ }^{11,11}$
}

To cite: Klang E, Soffer S, Zimlichman E, et al. Synergistic effect of hypoalbuminaemia and hypotension in predicting inhospital mortality and intensive care admission: a retrospective cohort study. BMJ Open 2021;11:e050216. doi:10.1136/ bmjopen-2021-050216

- Prepublication history and additional supplemental material for this paper are available online. To view these files, please visit the journal online (http://dx.doi.org/10.1136/ bmjopen-2021-050216).

Received 15 February 2021 Accepted 24 September 2021

Check for updates

(C) Author(s) (or their employer(s)) 2021. Re-use permitted under CC BY-NC. No commercial re-use. See rights and permissions. Published by BMJ.

For numbered affiliations see end of article.

Correspondence to

Dr Shelly Soffer;

soffer.shelly@gmail.com

\section{ABSTRACT}

Objective Hypoalbuminaemia is an important prognostic factor. It may be associated with poor nutritional states, chronic heart and kidney disease, long-standing infection and cancer. Hypotension is a hallmark of circulatory failure. We evaluated hypoalbuminaemia and hypotension synergism as predictor of in-hospital mortality and intensive care unit (ICU) admission.

Design We retrospectively analysed emergency department (ED) visits from January 2011 to December 2019.

Setting Data were retrieved from five Mount Sinai health system hospitals, New York.

Participants We included consecutive ED patients $\geq 18$ years with albumin measurements.

Primary and secondary outcome measures Clinical outcomes were in-hospital mortality and ICU admission. The rates of these outcomes were stratified by systolic blood pressure (SBP) ( $<90$ vs $\geq 90 \mathrm{~mm} \mathrm{Hg}$ ) and albumin levels. Variables included demographics, presenting vital signs, comorbidities (measured as ICD codes) and other common blood tests. Multivariable logistic regression models analysed the adjusted OR of different levels of albumin and SBP for predicting ICU admission and in-hospital mortality. The models were adjusted for demographics, vital signs, comorbidities and common laboratory results. Patients with albumin $3.5-4.5 \mathrm{~g} / \mathrm{dL}$ and $\mathrm{SBP} \geq 90 \mathrm{~mm} \mathrm{Hg}$ were used as reference.

Results The cohort included 402123 ED arrivals (27.9\% of total adult ED visits). The rates of in-hospital mortality, ICU admission and overall admission were 1.7\%, 8.4\% and $47.1 \%$, respectively. For SBP $<90 \mathrm{~mm} \mathrm{Hg}$ and albumin $<2.5 \mathrm{~g} / \mathrm{dL}$, mortality and ICU admission rates were $34.0 \%$ and $40.6 \%$, respectively; for SBP $<90 \mathrm{~mm}$ $\mathrm{Hg}$ and albumin $\geq 2.5 \mathrm{~g} / \mathrm{dL} 8.2 \%$ and $24.1 \%$, respectively; for SBP $\geq 90 \mathrm{~mm} \mathrm{Hg}$ and albumin $<2.5 \mathrm{~g} / \mathrm{dL} 11.4 \%$ and $18.6 \%$, respectively; for SBP $\geq 90 \mathrm{~mm} \mathrm{Hg}$ and albumin $3.5-4.5 \mathrm{~g} / \mathrm{dL} 0.5 \%$ and $6.4 \%$, respectively. Multivariable analysis showed that in patients with hypotension and albumin $<2.5 \mathrm{~g} / \mathrm{dL}$ the adjusted OR for in-hospital mortality was 37.1 (95\% Cl 32.3 to 42.6), and for ICU admission was $5.4(95 \% \mathrm{Cl} 4.8$ to 6.1$)$.

Conclusion Co-occurrence of hypotension and hypoalbuminaemia is associated with poor hospital outcomes.
Strengths and limitations of this study

- This was a large multicentre study. The albuminblood pressure synergism was evaluated for all emergency department (ED) patients with measurements.

- We evaluated the predictive value of albumin across different blood pressure levels, with emphasis on hypotension.

- We compared albumin to other common and important clinical markers in the ED.

- The study's limitations include its retrospective nature and its focus solely on in-hospital outcomes (inhospital mortality and intensive care unit admission).

\section{INTRODUCTION}

Clinicians rely on clinical and laboratory biomarkers for decision making. Hypoalbuminaemia has been widely studied. It has been associated with increased morbidity and mortality in many clinical conditions. A recent study showed that low albumin on admission is linked with increased in-hospital mortality. ${ }^{1}$ Other studies investigated hypoalbuminaemia in acute myocardial infarction, ${ }^{23}$ heart failure, ${ }^{4}$ sepsis, ${ }^{5}$ stroke,${ }^{6}$ burns ${ }^{7}$ and malignancies. ${ }^{8}$ It was demonstrated that marked hypoalbuminaemia was associated with $34 \%-80 \%$ mortality. $^{17}$

Albumin has important physiological functions such as maintenance of normal osmotic pressure, microvascular permeability and regulation of platelet aggregation. ${ }^{9}$ The link between hypoalbuminaemia and increased mortality could be attributed to the fact that hypoalbuminaemia reflects the severity of the systemic state. Hypoalbuminaemia is associated with poor nutritional status, frailty, severe hepatic or renal dysfunction, inflammation and late cancer states. ${ }^{9-12}$ 
Shock is defined as a circulatory failure with the hypoperfusion of tissues. Hypotension is a hallmark of circulatory failure. When it persists, it leads to shock. ${ }^{13-15}$

Serum albumin and systolic blood pressure (SBP) are widely used clinical measurements. Therefore, it is important to explore the interaction between these two parameters in a large-scale study. We evaluated hypoalbuminaemia and hypotension synergism as a predictor of in-hospital mortality and the need for intensive care unit (ICU) admission.

\section{MATERIALS AND METHODS \\ Study setting and data source}

We identified all consecutive admissions to five emergency departments (EDs) in the Mount Sinai health system (MSHS), New York, USA (Mount Sinai Hospital, Mount Sinai Brooklyn, Mount Sinai Queens, Mount Sinai Morningside and Mount Sinai West). Electronic health record (EHR) data were extracted from EPIC (Epic Systems, Verona, Wisconsin, USA). The study time frame was from 1 January 2011 to 31 December 2019.

The MSHS is a large, diverse health system. All included EDs in the study were co-located with a hospital. The approximate total numbers of yearly ED visits are 50 000-1 00000 per hospital. The approximate admission rate in the MSHS is $17 \%$.

\section{Study design \\ Population}

Patients were included in the analyses if they had an ED visit for any reason during the study period. We excluded patients younger than 18 , patients with records that were erroneously created, and visits without albumin measurements at admission. We also excluded patients with missing data regarding laboratory and vital signs.

\section{Variables}

The primary outcomes were all-cause in-hospital mortality and ICU admission. Covariates of interest included: age, sex, comorbidities (coded using International Classification of Diseases-10 Clinical Modification (ICD-10-CM) and grouped using the diagnostic clinical classification software: congestive heart failure (CHF), coronary artery disease $(\mathrm{CAD})$, diabetes mellitus (DM), hypertension (HTN), chronic kidney disease (CKD), chronic obstructive pulmonary disease (COPD) and known cancer),

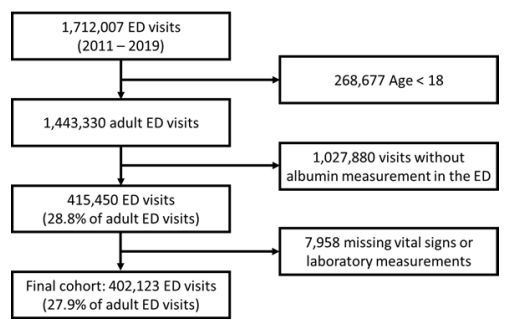

Figure 1 Study flow chart. ED, emergency department. first vital signs (SBP, diastolic blood pressure, heart rate, temperature, pulse oximetry, respiratory rate), and first commonly used laboratory test results in the ED (albumin, haemoglobin (HB), white blood cells (WBC), blood urea nitrogen (BUN), creatinine (CR), sodium, chloride, potassium).

ICD-10-CM codes were retrieved for each patient from the MSHS Epic EHR. All codes were limited to those registered prior to the index ED visit.

\section{Albumin and blood pressure groups selection}

Similar to previous publication, ${ }^{1}$ patients were clustered into five groups based on albumin levels at admission: albumin $<2.5 \mathrm{~g} / \mathrm{dL}$, albumin $\geq 2.5 \mathrm{~g} / \mathrm{dL}$ and $<3.5 \mathrm{~g} / \mathrm{dL}$, albumin $\geq 3.5 \mathrm{~g} / \mathrm{dL}$ and $<4.5 \mathrm{~g} / \mathrm{dL}$ and albumin $\geq 4.5 \mathrm{~g} /$ $\mathrm{dL}$. Patients were also defined as hypotensive $(\mathrm{SBP}<90$ $\mathrm{mm} \mathrm{Hg}$ ) based on their SBP at admission.

\section{Statistical analysis}

Descriptive statistics were reported for all patient characteristics using means and SD or medians with IQR for continuous variables and counts with percentages for categorical variables. Continuous variables were compared using either the unpaired t-test for two variables or one-way analysis of variance (ANOVA) for more than two variables. Categorical variables were compared using the $\chi^{2}$ test.

Patients were stratified according to the admission SBP (low $<90 \mathrm{~mm} \mathrm{Hg}$ and $\geq 90 \mathrm{~mm} \mathrm{Hg}$ ) and the admission serum albumin (low $<2.5 \mathrm{~g} / \mathrm{dL}, 2.5-3.0 \mathrm{~g} / \mathrm{dL}, 3.0-3.5 \mathrm{~g} /$ $\mathrm{dL}, 3.5-4.5 \mathrm{~g} / \mathrm{dL}$, and $>4.5 \mathrm{~g} / \mathrm{dL}$ ).

We estimated the predictive value of albumin for in-hospital mortality and ICU admission in hypotensive patients. For this, receiver operator curves (ROC) were plotted, and the area under the ROC (AUC) were computed. For informational basis, albumin AUCs were compared with the AUCs of other common clinical variables in the ED (age, HR, WBC, HGB, BUN, CR).

Two multivariable logistic regression models compared rates of outcomes between subgroups of patients stratified by albumin and SBP at admission levels: one model for in-hospital mortality prediction and one model for ICU admission. In each model there were ten combined albumin and SBP groups. Each albumin/SBP group represented a combination of one albumin level $(<2.5,2.5-3.5,3.5-4.5, \geq 4.5 \mathrm{~g} / \mathrm{dL})$ and one SBP at admission level $(<90$ or $\geq 90 \mathrm{~mm} \mathrm{Hg}$ ). In each model, patients that had both albumin 3.5-4.5 $\mathrm{g} / \mathrm{dL}$ and $\mathrm{SBP}$ at admission $\geq 90 \mathrm{~mm} \mathrm{Hg}$ constituted the reference group. The models were adjusted for important clinical variables in the ED. These included demographics (age, sex), vital signs (TEMP, HR, RR), comorbidities (CHF, CAD, DM, HTN, CKD, COPD, cancer) and laboratory results (WBC, HB, BUN, CR).

We have also analysed albumin and SBP at admission as continuous variables. We have thus built multivariable logistic regression models using the same outcomes and covariates, with albumin and SBP at admission as continuous variables. 
Table 1 Table shows the demographic, clinical and biochemical characteristics of adult patients presenting in the ED, stratified by admission albumin level

\begin{tabular}{|c|c|c|c|c|c|c|}
\hline & $\begin{array}{l}\text { Albumin }<2.5 \\
\text { g/dL } \\
(n=17 \quad 153,4.3 \%)\end{array}$ & $\begin{array}{l}\text { Albumin } \geq 2.5 \mathrm{~g} / \\
\mathrm{dL} \text { and }<3.0 \mathrm{~g} / \mathrm{dL} \\
(\mathrm{n}=27867,6.9 \%)\end{array}$ & $\begin{array}{l}\text { Albumin } \geq 3.0 \mathrm{~g} / \\
\mathrm{dL} \text { and }<3.5 \mathrm{~g} / \mathrm{dL} \\
(\mathrm{n}=63683,15.8 \%)\end{array}$ & $\begin{array}{l}\text { Albumin } \geq 3.5 \mathrm{~g} / \mathrm{dL} \\
\text { and }<4.5 \mathrm{~g} / \mathrm{dL} \\
(\mathrm{n}=247432,61.5 \%)\end{array}$ & $\begin{array}{l}\text { Albumin } \geq 4.5 \\
\mathrm{~g} / \mathrm{dL} \\
(\mathrm{n}=45988, \\
11.4 \%)\end{array}$ & $\mathrm{P}$ value \\
\hline Age, median (IQR), year & $64(54-76)$ & $66(54-79)$ & $65(51-78)$ & $53(37-68)$ & $36(27-53)$ & $<0.001$ \\
\hline Female, N (\%) & $8126(47.4)$ & $14242(51.1)$ & $36164(56.8)$ & $143746(58.1)$ & $20490(44.6)$ & $<0.001$ \\
\hline DBP, median (IQR), mm Hg & $66(57-77)$ & $69(60-79)$ & $72(64-82)$ & $77(68-86)$ & $79(70-88)$ & $<0.001$ \\
\hline Heart rate, median (IQR), b/min & $92(79-107)$ & $89(76-104)$ & $87(75-100)$ & $84(73-97)$ & $86(74-99)$ & $<0.001$ \\
\hline $\begin{array}{l}\text { Temperature, median (IQR), } \\
\text { Celsius }\end{array}$ & $36.7(36.2-37.1)$ & $36.7(36.3-37.1)$ & $36.7(36.3-37.0)$ & $36.7(36.3-36.9)$ & $36.6(36.2-36.9)$ & $<0.001$ \\
\hline \multicolumn{7}{|l|}{ Comorbidities } \\
\hline CAD, N (\%) & $3167(18.5)$ & $6362(22.8)$ & $14428(22.7)$ & 32079 (13.0) & $2240(4.9)$ & $<0.001$ \\
\hline CHF, N (\%) & $4032(23.5)$ & $7429(26.7)$ & $14722(23.1)$ & $23756(9.6)$ & $1446(3.1)$ & $<0.001$ \\
\hline $\mathrm{DM}, \mathrm{N}(\%)$ & $6877(40.1)$ & 11123 (39.9) & $23563(37.0)$ & $58244(23.5)$ & $5849(12.7)$ & $<0.001$ \\
\hline HTN, N (\%) & $8251(48.1)$ & 14535 (52.2) & 31679 (49.7) & $78625(31.8)$ & $7223(15.7)$ & $<0.001$ \\
\hline CKD, N (\%) & $4011(23.4)$ & $6673(23.9)$ & 12528 (19.7) & $19962(8.1)$ & 1464 (3.2) & $<0.001$ \\
\hline COPD, N (\%) & $1944(11.3)$ & 3765 (13.5) & $8804(13.8)$ & $18092(7.3)$ & $1264(2.7)$ & $<0.001$ \\
\hline Cancer, N (\%) & $6821(39.8)$ & $9849(35.3)$ & 17788 (27.9) & 41605 (16.8) & $4355(9.5)$ & $<0.001$ \\
\hline \multicolumn{7}{|l|}{ Laboratory results } \\
\hline $\mathrm{K}$, median (IQR), mEq/L & $4.1(3.6-4.8)$ & $4.2(3.7-4.7)$ & $4.1(3.7-4.6)$ & $4.0(3.7-4.4)$ & $4.0(3.7-4.3)$ & $<0.001$ \\
\hline \multicolumn{7}{|l|}{ Admission } \\
\hline Hospital admission & 14633 (85.3) & 21764 (78.1) & 40953 (64.3) & 96682 (39.1) & 15176 (33.0) & \\
\hline
\end{tabular}

*Total number included in the cohort 407492.

†Way analysis of variance estimated statistical difference between the different albumin groups.

BUN, blood urea nitrogen; CAD, coronary artery disease; CHF, congestive heart failure; CKD, chronic kidney disease; COPD, chronic obstructive pulmonary disease; CR, creatinine; DBP, diastolic blood pressure; DM, diabetes mellitus; ED, emergency department; HGB, haemoglobin; HTN, hypertension; K, potassium; Na, sodium; NEUT, absolute neutrophil count; SBP, systolic blood pressure; WBC, white blood cells.

A correlation matrix was constructed to assess the possible collinearity between covariates. All covariate correlations were below 0.7. Adjusted OR with $95 \%$ CIs were reported.

AUCs, also known as C-statistics, were calculated for each multivariable model. Bootstrapping validations (1000 bootstrap resamples) were used to calculate $95 \%$ CIs for all metrics.

All analyses were conducted with Python (Python software foundation, V.3.6.5). Statistical significance was established at a two-sided $\mathrm{p}<0.05$.

\section{Patient and public involvement}

No patients were involved in the formulation of the study.

\section{RESULTS}

Our final cohort comprised 407492 patients $\geq 18$ years old who had albumin measured in the ED and had complete vital signs (27.9\% of the adult ED population). Figure 1 presents the study inclusion flow chart. The median age in the cohort was 55 (IQR 37-71) years, and $222768(55.4 \%)$ patients were females (table 1$)$. Of the 


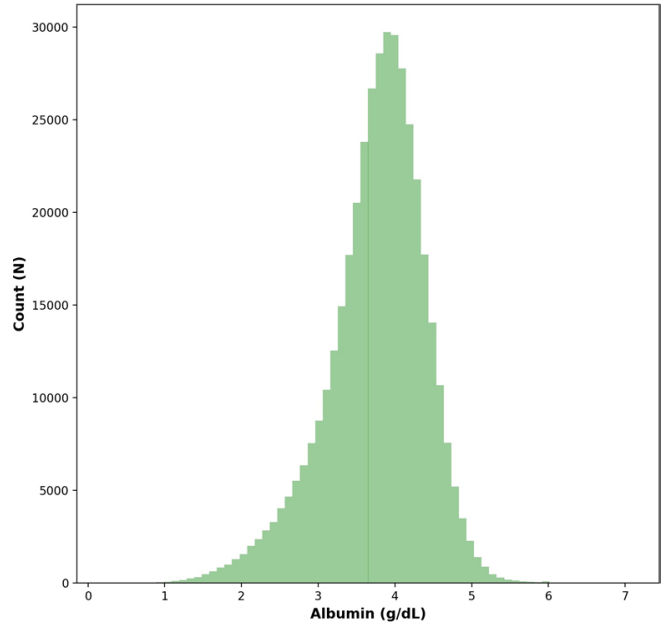

Figure 2 Distribution plot of albumin levels in the study cohort.

ED visits, 189208 (47.1\%) were admitted to the hospital. The overall in-hospital mortality rate was $1.7 \%(n=6729)$. The ICU admission rate was $8.4 \%(n=33780)$.

\section{Albumin and SBP}

The albumin distribution was left-skewed (figure 2), with a median of $3.8 \mathrm{~g} / \mathrm{dL}$ (IQR 3.4-4.2). Hypoalbuminaemia $(<3.5 \mathrm{~g} / \mathrm{dL})$ was found in $27.0 \%$ of the cohort; $11.2 \%$ had albumin $<3.0 \mathrm{~g} / \mathrm{dL}$ and $4.3 \% \mathrm{had}$ albumin $<2.5 \mathrm{~g} / \mathrm{dL}$. SBP at admission showed a median of 132 (IQR 118-151) (figure 3). $1.7 \%$ of the cohort had SBP $<90 \mathrm{~mm} \mathrm{Hg}$ at admission.

Patients with hypoalbuminaemia had significantly more comorbidities (cancer $31.7 \%$ in patients with hypoalbuminaemia vs $15.7 \%$ without hypoalbuminaemia; cardiovascular disease $33.9 \%$ in patients with hypoalbuminaemia vs $15.9 \%$ without hypoalbuminaemia). These patients also had lower HGB, with a median HGB of 9.6 in the $<2.5 \mathrm{~g} / \mathrm{dL}$ albumin group (table 1 ).

Compared with common clinical and laboratory markers measured on ED admission, albumin was the best predictor of both in-hospital mortality and ICU admission

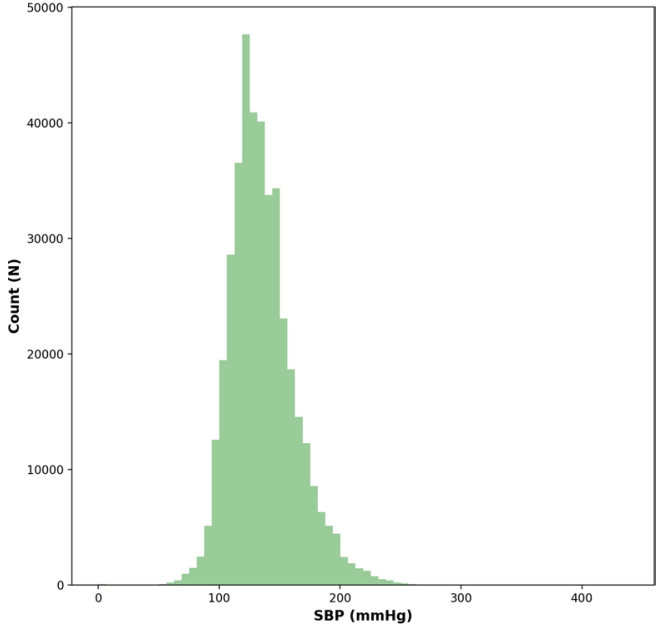

Figure 3 Distribution plot of systolic blood pressure (SBP) in the study cohort.

(figure 4A,B). In the hypotensive group, albumin showed an AUC of 0.77 (95\% CI 0.75 to 0.78 ) for predicting in-hospital mortality. It also established an AUC of 0.64 (95\% CI 0.63 to 0.65 ) for predicting ICU admission.

\section{Multivariable models}

The rates of outcomes were significantly associated with SBP at admission and albumin synergism (figure 5A,B). The co-occurrence of SBP at admission $<90 \mathrm{~mm} \mathrm{Hg}$ and albumin $<2.5 \mathrm{~g} / \mathrm{dL}$ was associated with $34.0 \%$ in-hospital mortality and $40.6 \%$ ICU admission rates. In comparison, in patients with SBP at admission $<90 \mathrm{~mm} \mathrm{Hg}$ but albumin $\geq 2.5 \mathrm{~g} / \mathrm{dL}$, an in-hospital mortality rate of $8.2 \%$, and ICU admission rates of $24.1 \%$ were observed. In patients with albumin $<2.5 \mathrm{~g} / \mathrm{dL}$ but $\mathrm{SBP}$ at admission $\geq 90$ $\mathrm{mm} \mathrm{Hg}$, an in-hospital mortality rate of $11.4 \%$ and ICU admission rates of $18.6 \%$ were observed.

The multivariable logistic regression models adjusting for demographics, vital signs, comorbidities and blood test results had C-statistics of 0.89 (95\% CI 0.89 to 0.90$)$ for in-hospital mortality and 0.75 (95\% CI 0.74 to 0.75 ) for ICU admittance. The adjusted ORs of all the features

B

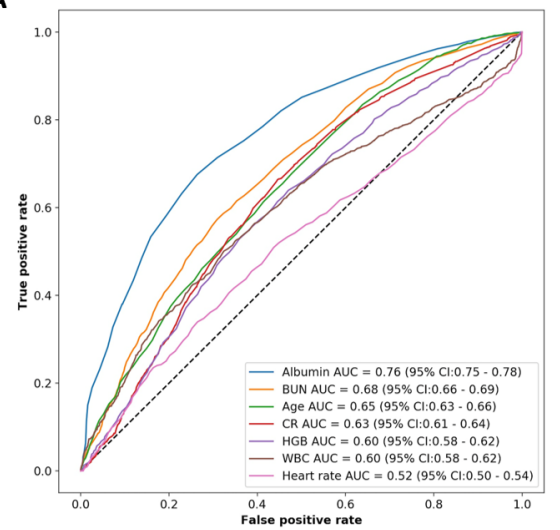

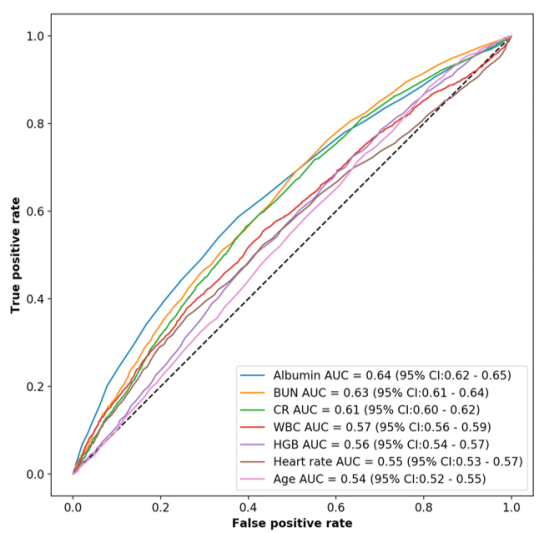

Figure 4 Receiver operator curves (ROC) and areas under the ROC curves (AUC) for the hypotensive cohort comparing the predictive ability of albumin for (A) in-hospital mortality and (B) ICU admission, with comparison to other clinical variables. BUN, blood urea nitrogen; CR, creatinine; HGB, haemoglobin; ICU, intensive care unit; WBC, white blood cells. 


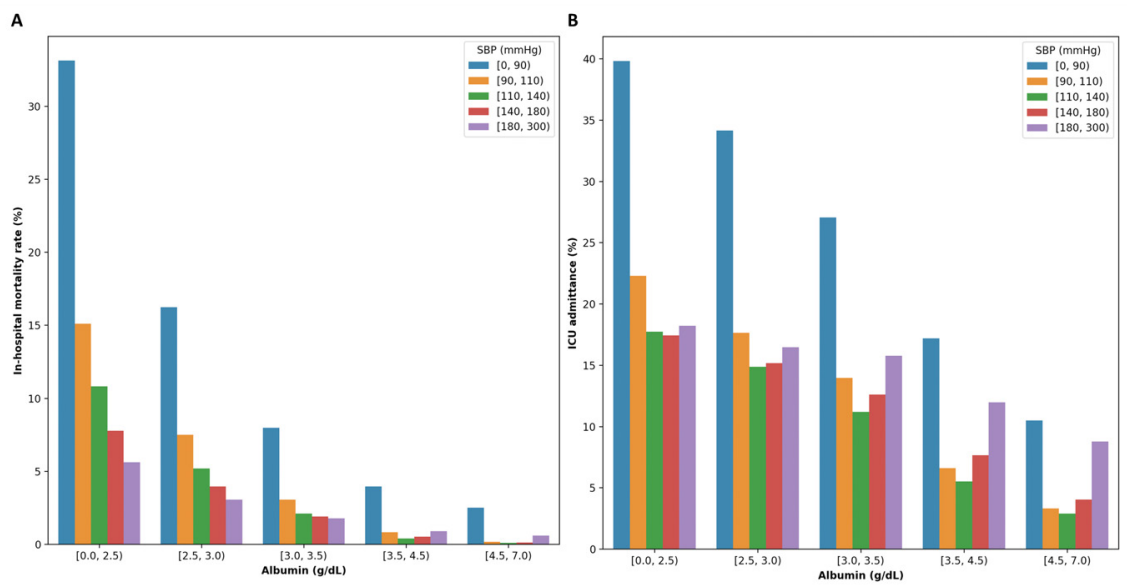

Figure 5 (A) All cause in-hospital mortality rate and (B) ICU admission rate stratified by albumin and SBP groups. ICU, intensive care unit; SBP, systolic blood pressure.

in the models are presented in online supplemental tables 1,2 .

Adjusted aORs were similar to the crude rates (tables 2 and 3). The aORs for in-hospital mortality in patients with albumin $<2.5 \mathrm{~g} / \mathrm{dL}$ and hypotension was 37.1 (95\% CI 32.3 to 42.6$)$. The aOR for ICU admission in this group was $5.4(95 \%$ CI 4.8 to 6.1$)$.

In the multivariable logistic regression models, using albumin and SBP at admission as continuous variables, the adjusted OR of albumin for in-hospital mortality was 0.3 (95\% CI 0.3 to 0.3 ) and the adjusted OR of SBP at admission was 0.9 (95\% CI 0.9 to 0.9 ). For ICU admission, the adjusted OR of albumin was 0.6 (95\% CI 0.6 to 0.6 ) and the adjusted OR of SBP at admission was 1.0 (95\% CI 1.0 to 1.0). Online supplemental tables 3 and 4 present the adjusted ORs of all covariates in these models.

\section{DISCUSSION}

Both albumin and SBP are important clinical markers. Abnormalities in these indices may signify severe outcomes. Thus, it is important to elucidate the interaction between these two parameters. We found that in ED patients, the combination of hypoalbuminaemia and hypotension showed a strong synergistic effect for in-hospital mortality and ICU admission.

Several previous studies evaluated the significance of albumin levels in shock and preshock states. Holder et al analysed $582 \mathrm{ED}$ patients with sepsis without organ failure or shock. They found that albumin below $3.5 \mathrm{~g} / \mathrm{dL}$ was an indicator for progression to severe sepsis or shock. ${ }^{16}$ This study excluded patients with $\mathrm{SBP}<90 \mathrm{~mm} \mathrm{Hg}$ at admission. Another study analysed 561 patients admitted to the ED with sepsis. In this study, admission albumin levels were associated with 28-day mortality. ${ }^{17}$ Arteo et al analysed 112 patients with septic shock or severe sepsis. They showed that hypoalbuminaemia was the most important prognostic factor in community-acquired bloodstream infection with severe sepsis. ${ }^{18}$

It was recently demonstrated that hypoalbuminaemia is an important prognostic marker in cardiogenic shock. ${ }^{19}$

Table 2 All-cause in-hospital mortality in adult patients presenting in the ED, stratified by admission albumin level and blood pressure

\begin{tabular}{|c|c|c|c|c|c|c|}
\hline & & $\begin{array}{l}\text { Albumin }<2.5 \\
\text { g/dL }\end{array}$ & $\begin{array}{l}\text { Albumin } \geq 2.5 \mathrm{~g} / \mathrm{dL} \\
\text { and }<3.0 \mathrm{~g} / \mathrm{dL}\end{array}$ & $\begin{array}{l}\text { Albumin } \geq 3.0 \mathrm{~g} / \mathrm{dL} \\
\text { and }<3.5 \mathrm{~g} / \mathrm{dL}\end{array}$ & $\begin{array}{l}\text { Albumin } \geq 3.5 \mathrm{~g} / \mathrm{dL} \\
\text { and }<4.5 \mathrm{~g} / \mathrm{dL}\end{array}$ & $\begin{array}{l}\text { Albumin } \geq 4.5 \mathrm{~g} / \\
\mathrm{dL}\end{array}$ \\
\hline \multirow{2}{*}{$\begin{array}{l}\text { Crude in- } \\
\text { hospital } \\
\text { mortality } \\
\text { rates }\end{array}$} & $\begin{array}{l}\mathrm{SBP}<90 \\
\mathrm{~mm} \mathrm{Hg}\end{array}$ & $\begin{array}{l}527 / 1548 \\
(34.0 \%)\end{array}$ & $\begin{array}{l}212 / 1270 \\
(16.7 \%)\end{array}$ & $\begin{array}{l}132 / 1595 \\
(8.3 \%)\end{array}$ & $\begin{array}{l}85 / 2204 \\
(3.9 \%)\end{array}$ & $\begin{array}{l}4 / 194 \\
(2.1 \%)\end{array}$ \\
\hline & $\begin{array}{l}\mathrm{SBP} \geq 90 \\
\mathrm{~mm} \mathrm{Hg}\end{array}$ & $\begin{array}{l}1787 / 15605 \\
(11.5 \%)\end{array}$ & $\begin{array}{l}1431 / 26597 \\
(5.4 \%)\end{array}$ & $\begin{array}{l}1294 / 62088 \\
(2.1 \%)\end{array}$ & $\begin{array}{l}1194 / 245228 \\
(0.5 \%)\end{array}$ & $\begin{array}{l}63 / 45794 \\
(0.1 \%)\end{array}$ \\
\hline \multirow{2}{*}{$\begin{array}{l}\text { Adjusted } \\
\text { OR for in- } \\
\text { hospital } \\
\text { mortality }\end{array}$} & $\begin{array}{l}\mathrm{SBP}<90 \\
\mathrm{~mm} \mathrm{Hg}\end{array}$ & $\begin{array}{l}37.1(95 \% \mathrm{Cl} \\
32.3 \text { to } 42.6) \\
p<0.001\end{array}$ & $\begin{array}{l}14.2(95 \% \mathrm{Cl} 11.9 \text { to } \\
16.9) \\
\mathrm{p}<0.001\end{array}$ & $\begin{array}{l}7.2(95 \% \text { Cl } 5.9 \text { to } \\
8.8) \\
p<0.001\end{array}$ & $\begin{array}{l}4.6(95 \% \mathrm{Cl} 3.7 \text { to } \\
5.8) \\
p<0.001\end{array}$ & $\begin{array}{l}3.1(95 \% \mathrm{Cl} 1.1 \\
\text { to } 8.5) \\
p=0.029\end{array}$ \\
\hline & $\begin{array}{l}\mathrm{SBP} \geq 90 \\
\mathrm{~mm} \mathrm{Hg}\end{array}$ & $\begin{array}{l}12.9(95 \% \mathrm{Cl} \\
11.8 \text { to } 14.1) \\
\mathrm{p}<0.001\end{array}$ & $\begin{array}{l}5.9(95 \% \text { Cl } 5.4 \text { to } \\
6.5) \\
p<0.001\end{array}$ & $\begin{array}{l}2.7(95 \% \mathrm{Cl} 2.5 \text { to } \\
2.9) \\
\mathrm{p}<0.001\end{array}$ & $\begin{array}{l}1 \\
\text { (Reference) }\end{array}$ & $\begin{array}{l}0.4(95 \% \text { Cl } 0.3 \\
\text { to } 0.5) \\
p<0.001\end{array}$ \\
\hline
\end{tabular}

Adjusted ORs from multivariable logistic regression analyses adjusted for demographics, vital signs, comorbidities and blood test results. The table presents the crude rates and the multivariable-adjusted ORs.

ED, emergency department; SBP, systolic blood pressure. 
Table 3 ICU admission in adult patients presenting in the ED, stratified by admission albumin level and blood pressure

\begin{tabular}{|c|c|c|c|c|c|c|}
\hline & & $\begin{array}{l}\text { Albumin }<2.5 \\
\mathrm{~g} / \mathrm{dL}\end{array}$ & $\begin{array}{l}\text { Albumin } \geq 2.5 \mathrm{~g} / \mathrm{dL} \\
\text { and }<3.0 \mathrm{~g} / \mathrm{dL}\end{array}$ & $\begin{array}{l}\text { Albumin } \geq 3.0 \mathrm{~g} / \mathrm{dL} \\
\text { and }<3.5 \mathrm{~g} / \mathrm{dL}\end{array}$ & $\begin{array}{l}\text { Albumin } \geq 3.5 \mathrm{~g} / \mathrm{dL} \\
\text { and }<4.5 \mathrm{~g} / \mathrm{dL}\end{array}$ & Albumin $\geq 4.5 \mathrm{~g} / \mathrm{dL}$ \\
\hline \multirow{2}{*}{$\begin{array}{l}\text { Crude ICU } \\
\text { admission } \\
\text { rates }\end{array}$} & $\begin{array}{l}\mathrm{SBP}<90 \\
\mathrm{~mm} \mathrm{Hg}\end{array}$ & $\begin{array}{l}629 / 1548 \\
(40.6 \%)\end{array}$ & $\begin{array}{l}435 / 1270 \\
(34.3 \%)\end{array}$ & $\begin{array}{l}434 / 1595 \\
(27.2 \%)\end{array}$ & $\begin{array}{l}382 / 2204 \\
(17.3 \%)\end{array}$ & $\begin{array}{l}19 / 194 \\
(9.8 \%)\end{array}$ \\
\hline & $\begin{array}{l}\mathrm{SBP} \geq 90 \\
\mathrm{~mm} \mathrm{Hg}\end{array}$ & $\begin{array}{l}2915 / 15605 \\
(18.7 \%)\end{array}$ & $4131 / 26597$ (15.5\%) & $\begin{array}{l}7464 / 62088 \\
(12.0 \%)\end{array}$ & $\begin{array}{l}15763 / 245228 \\
(6.4 \%)\end{array}$ & $1608 / 45794$ (3.5\%) \\
\hline \multirow{2}{*}{$\begin{array}{l}\text { Adjusted } \\
\text { OR for } \\
\text { ICU } \\
\text { admission }\end{array}$} & $\begin{array}{l}\mathrm{SBP}<90 \\
\mathrm{~mm} \mathrm{Hg}\end{array}$ & $\begin{array}{l}5.4(95 \% \mathrm{Cl} 4.8 \\
\text { to } 6.1) \\
\mathrm{p}<0.001\end{array}$ & $\begin{array}{l}4.0(95 \% \mathrm{Cl} 3.5 \text { to } \\
4.5) \\
\mathrm{p}<0.001\end{array}$ & $\begin{array}{l}3.0(95 \% \mathrm{Cl} 2.7 \text { to } \\
3.4) \\
p<0.001\end{array}$ & $\begin{array}{l}2.1(95 \% \mathrm{Cl} 1.9 \text { to } \\
2.4) \\
\mathrm{p}<0.001\end{array}$ & $\begin{array}{l}1.3(95 \% \mathrm{Cl} 0.8 \text { to } \\
2.1) \\
p=0.319\end{array}$ \\
\hline & $\begin{array}{l}\mathrm{SBP} \geq 90 \\
\mathrm{~mm} \mathrm{Hg}\end{array}$ & $\begin{array}{l}2.2(95 \% \mathrm{Cl} 2.1 \\
\text { to } 2.3) \\
\mathrm{p}<0.001\end{array}$ & $\begin{array}{l}1.7(95 \% \mathrm{Cl} 1.6 \text { to } \\
1.8) \\
\mathrm{p}<0.001\end{array}$ & $\begin{array}{l}1.4(95 \% \mathrm{Cl} 1.4 \text { to } \\
1.4) \\
p<0.001\end{array}$ & $\begin{array}{l}1 \\
\text { (Reference) }\end{array}$ & $\begin{array}{l}0.7(95 \% \mathrm{Cl} 0.7 \text { to } \\
0.7) \\
p<0.001\end{array}$ \\
\hline
\end{tabular}

Adjusted ORs from multivariable logistic regression analyses adjusted for demographics, vital signs, comorbidities and blood test results. The table presents the crude rates and the multivariable-adjusted ORs.

ED, emergency department; ICU, intensive care unit; SBP, systolic blood pressure.

In this study, hypoalbuminaemia patients had a higher in-hospital mortality rate ( $48 \%$ vs $23 \%)$.

It has been suggested that hypoalbuminaemia may play a direct role in poor reperfusion. ${ }^{20}$ The co-occurrence of hypoalbuminaemia and hypotension may reflect a decrease in blood flow to vital organs. Additionally, low albumin leads to colloid oncotic pressure which in turn leads to hypovolaemia and hypotension. ${ }^{21}$ Previous studies have suggested that hypoalbuminaemia is associated with pre-existing disease severity. ${ }^{22}$ It was also shown that a low albumin level is linked to frailty and impaired nutritional status. ${ }^{12} 23$ Thus, albumin expresses a poor performance status. Indeed, patients with hypoalbuminaemia had more comorbidities and lower HB levels. However, low albumin remained a significant prognostic predictor after adjustment for comorbidities.

Our research was a large multisite study. As expected in such a large cohort, all ANOVA p values were statistically significant (table 1).

It should be noted that the in-hospital mortality adjusted rates were pretty similar to the crude rates, highlighting fragility of the results. In other words, sicker patients have lower albumin levels and are hypotensive and are more likely to suffer in-hospital mortality.

Our study on a large cohort augments the results of previous studies. We showed the importance of albumin to stratify ED hypotensive patients. Hypotensive patients that also present with hypoalbuminaemia are particularly at risk and should receive maximal attention. Information regarding low albumin in hypotensive patients should lead to a higher level of monitoring than indicated by vital signs and clinical impression alone. In addition, the presence of hypoalbuminaemia in hypotensive patients should result in a more accurate placement (ie, the need for ICU admission) and optimal hospital care.

Moreover, in-hospital mortality and ICU admission rates were stratified by albumin levels across all SBP at admission levels. After adjustment, the results hold with a C-statistic of 0.89 for in-hospital mortality and 0.75 for ICU admission. The models have higher AUC than albumin alone since they use data from albumin, SBP at admission as well as all the other covariates.

This study has several limitations. It is an observational study limited to the urban NYC area. Thus, it is unclear whether the results could be generalised to other settings. Second, we do not have information regarding post-discharge outcomes. Nonetheless, all-cause in-hospital mortality and ICU admission are important clinical outcomes. Third, we evaluated SBP at admission as an isolated marker. We did not stratify SBP at admission into septic or cardiogenic shock. Forth, ED lactate measurements were missing for most of the cohort (53.0\%). Thus, we did not include them in the multivariate analysis. Fifth, comorbidities were determined based on ICD$10-\mathrm{CM}$ records, which is prone to bias. Lastly, the study is biased by including only patients who underwent albumin measurement in the ED. Future research should evaluate the clinical applicability of the results including the clinical value of albumin assessment in the ED and potential intervention.

In conclusion, the co-occurrence of hypotension and hypoalbuminaemia is an important ominous sign in the ED.

\section{Author affiliations}

${ }^{1}$ Department of Diagnostic Imaging, Sheba Medical Center, Tel Hashomer, Israel ${ }^{2}$ Sackler Medical School, Tel Aviv University, Tel Aviv, Israel

${ }^{3}$ Internal Medicine B, Assuta Medical Center, Ashdod, Israel

${ }^{4}$ Ben-Gurion University of the Negev, Be'er Sheva, Israel

${ }^{5}$ Hospital management, Sheba Medical Center, Tel Hashomer, Israel

${ }^{6}$ Department of Emergency Medicine, Icahn School of Medicine at Mount Sinai, New York, New York, USA

${ }^{7}$ Institute for Translational Epidemiology, Icahn School of Medicine at Mount Sinai, New York, New York, USA

${ }^{8}$ Department of Genetics and Genomic Sciences, Icahn School of Medicine at Mount Sinai, New York, New York, USA

${ }^{9}$ Internal medicine Wing, Sheba Medical Center, Tel Hashomer, Israel

${ }^{10}$ Department of Anesthesiology, Perioperative and Pain Medicine, Icahn School of Medicine at Mount Sinai, New York, New York, USA 
${ }^{11}$ Department of Population Health Science and Policy, Icahn School of Medicine at Mount Sinai, New York, New York, USA

\section{Twitter Benjamin S Glicksberg @BenGlicksberg}

Contributors EK, SS, EZ, AZ, BSG, EG, DLR, RF and MAL developed the study concept and design. EK carried out the data analysis. EK and SS drafted the manuscript. EZ, AZ, BSG, EG, DLR, RF and MAL contributed to the interpretation of the results and critical review of the manuscript. EK is the guarantors of this work and, as such, had full access to all the data in the study and take responsibility for the integrity of the data and the accuracy of the data analysis.

Funding The authors have not declared a specific grant for this research from any funding agency in the public, commercial or not-for-profit sectors.

Competing interests None declared.

Patient consent for publication Not applicable.

Ethics approval An institutional review board (IRB) of the Mount Sinai health system approved this retrospective cohort study (STUDY-18-00573). The IRB committee waived informed consent.

Provenance and peer review Not commissioned; externally peer reviewed.

Data availability statement Data are available on reasonable request. Anonymized participant data are held in a secure research server and will be handled in accordance with the ethical approval for this project.

Supplemental material This content has been supplied by the author(s). It has not been vetted by BMJ Publishing Group Limited (BMJ) and may not have been peer-reviewed. Any opinions or recommendations discussed are solely those of the author(s) and are not endorsed by BMJ. BMJ disclaims all liability and responsibility arising from any reliance placed on the content. Where the content includes any translated material, BMJ does not warrant the accuracy and reliability of the translations (including but not limited to local regulations, clinical guidelines, terminology, drug names and drug dosages), and is not responsible for any error and/or omissions arising from translation and adaptation or otherwise.

Open access This is an open access article distributed in accordance with the Creative Commons Attribution Non Commercial (CC BY-NC 4.0) license, which permits others to distribute, remix, adapt, build upon this work non-commercially, and license their derivative works on different terms, provided the original work is properly cited, appropriate credit is given, any changes made indicated, and the use is non-commercial. See: http://creativecommons.org/licenses/by-nc/4.0/.

ORCID iD

Shelly Soffer http://orcid.org/0000-0002-7853-2029

\section{REFERENCES}

1 Akirov A, Masri-Iraqi $\mathrm{H}$, Atamna A, et al. Low albumin levels are associated with mortality risk in hospitalized patients. Am J Med 2017;130:1465.e11-e19.

2 Plakht Y, Gilutz H, Shiyovich A. Decreased admission serum albumin level is an independent predictor of long-term mortality in hospital survivors of acute myocardial infarction. Soroka acute myocardial infarction II (SAMI-II) project. Int J Cardiol 2016;219:20-4.

3 Djoussé L, Rothman KJ, Cupples LA, et al. Serum albumin and risk of myocardial infarction and all-cause mortality in the Framingham offspring study. Circulation 2002;106:2919-24.
4 Arques S, Roux E, Sbragia P, et al. Usefulness of serum albumin concentration for in-hospital risk stratification in frail, elderly patients with acute heart failure. insights from a prospective, monocenter study. Int J Cardiol 2008;125:265-7.

5 Takegawa R, Kabata D, Shimizu K, et al. Serum albumin as a risk factor for death in patients with prolonged sepsis: an observational study. J Crit Care 2019;51:139-44.

6 Cho Y-M, Choi I-S, Bian R-X, et al. Serum albumin at admission for prediction of functional outcome in ischaemic stroke patients. Neurol Sci 2008;29:445-9.

7 Aguayo-Becerra OA, Torres-Garibay C, Macías-Amezcua MD, et al. Serum albumin level as a risk factor for mortality in burn patients. Clinics 2013;68:940-5.

8 Boonpipattanapong T, Chewatanakornkul S. Preoperative carcinoembryonic antigen and albumin in predicting survival in patients with colon and rectal carcinomas. J Clin Gastroenterol 2006;40:592-5.

9 Soeters PB, Wolfe RR, Shenkin A. Hypoalbuminemia: pathogenesis and clinical significance. JPEN J Parenter Enteral Nutr 2019;43:181-93.

10 Marcason W. Should albumin and prealbumin be used as indicators for malnutrition? J Acad Nutr Diet 2017;117:1144.

11 Almasaudi AS, Dolan RD, Edwards CA, et al. Hypoalbuminemia reflects nutritional risk, body composition and systemic inflammation and is independently associated with survival in patients with colorectal cancer. Cancers 2020;12:1986.

12 Wiley Online Library. Poor nutritional status and inflammation: serum albumin: relationship to inflammation and nutrition. Seminars in Dialysis 2004

13 Holler JG, Bech CN, Henriksen DP, et al. Nontraumatic hypotension and shock in the emergency department and the prehospital setting, prevalence, etiology, and mortality: a systematic review. PLoS One 2015;10:e0119331.

14 Klang E, Soffer S, Shimon Shahar M. Association of normal systolic blood pressure in the emergency department with higher in-hospital mortality among hypertensive patients. 2019;21:1841-8.

15 Meltzer SJ. The nature of shock. Arch Intern Med 1908;1:571-88.

16 Holder AL, Gupta N, Lulaj E, et al. Predictors of early progression to severe sepsis or shock among emergency department patients with nonsevere sepsis. Int J Emerg Med 2016;9:10.

17 Seo MH, Choa M, You JS, et al. Hypoalbuminemia, low base excess values, and tachypnea predict 28-day mortality in severe sepsis and septic shock patients in the emergency department. Yonsei Med $J$ 2016;57:1361-9.

18 Artero A, Zaragoza R, Camarena JJ, et al. Prognostic factors of mortality in patients with community-acquired bloodstream infection with severe sepsis and septic shock. J Crit Care 2010;25:276-81.

19 Jantti T, Tarvasmaki T. Hypoalbuminemia is a frequent marker of increased mortality in cardiogenic shock. 2019;14:e0217006.

20 Oduncu V, Erkol A, Karabay CY, et al. The prognostic value of serum albumin levels on admission in patients with acute ST-segment elevation myocardial infarction undergoing a primary percutaneous coronary intervention. Coron Artery Dis 2013;24:88-94.

21 Darwish A, Lui F. Physiology, colloid osmotic pressure. Stat Pearls 2020.

22 Goldwasser P, Feldman J. Association of serum albumin and mortality risk. J Clin Epidemiol 1997;50:693-703.

23 Forse RA, Shizgal HM. Serum albumin and nutritional status. JPEN Parenter Enteral Nutr 1980;4:450-4. 